\title{
EDITORIAL
}

\section{Denise Maurano}

Joana Souza

\section{ENTRE HARVARD E UGANDA hÁ O SE(E)R}

Quinze anos se passaram desde que a primeira edição da Psicanálise \& Barroco foi publicada na web. Idealizada pela Prof ${ }^{a}$ Denise Maurano durante sua passagem pela Universidade Federal de Juiz de Fora, a revista nasceu em 2003 pelo esforço conjunto da equipe que compunha o Núcleo de Estudos e Pesquisa em Subjetividade e Cultura. Em 2010 passou a compor o quadro de periódicos da Universidade Federal do Estado do Rio de Janeiro (UNIRIO), onde se encontra vinculada à linha de pesquisa Memória, Subjetividade e Criação do Programa de PósGraduação em Memória Social.

Recentemente, a Psicanálise \& Barroco em revista migrou para o Sistema Eletrônico de Editoração de Revistas (SEER), um software desenvolvido para a construção e gestão de uma publicação periódica eletrônica. Esta ferramenta contempla ações essenciais à automação das atividades de editoração de periódicos científicos. Recomendado pela CAPES, o processo editorial no SEER permite uma melhoria na avaliação da qualidade dos periódicos e uma maior rapidez no fluxo das informações. Esse sistema, além de garantir a autonomia da gestão das edições pela equipe, permite que a revista esteja em conexão com os principais indexadores da América Latina.

Há muito ansiávamos por essa migração, mas diversas questões de caráter estrutural adiaram esse projeto que agora então se concretiza. Certamente a ampliação de nossa equipe e a dedicação de seus membros foram cruciais para a realização desse intento. Em nosso país, sobretudo em tempos sombrios como os que vivemos agora, conseguir avançar projetos de natureza cultural, diante da difícil tarefa de atendermos a exigências que encontram-se no nível da Universidade de Harvard, com condições de trabalho, muitas vezes similares as de Uganda, é um exercício que nos testa diariamente. Por isso, vencer os obstáculos, conseguindo ainda melhorar nossa qualidade, é motivo de satisfação ainda mais especial. Nossos 
valores humanos são nosso maior patrimônio, e nesse sentido a afinação de nossa equipe tem orquestrado essa nossa partitura. Assim, há muito que comemorar!

Na décima sexta edição da Psicanálise \& Barroco em revista, apresentamos a nossos leitores uma seleção de artigos que foram agrupados em duas seções: uma de artigos temáticos, no caso, psicanálise e literatura, e outra de temas livres que contemplem os saberes que privilegiamos.

Na seção de artigos temáticos, a interlocução entre psicanálise e literatura é privilegiada por quatro autores. Em "Entre dores: Judith e Florbela", a autora Eliana Luiza dos Santos Barros, munida de uma sensibilidade que the é peculiar, retoma a obra dessas poetisas portuguesas, para mostrar como a escrita literária é um canal possível para dizer sobre a dor que atravessa o universo das mulheres. A autora indica a existência de um encontro entre a escrita de Judith e Florbela e a psicanálise, na medida em que ambas constroem um saber sobre a dor de existir.

Esse caminho também foi seguido por Tiago Antonio Sampaio em "Poesia e Psicanálise: um possível diálogo entre Manoel de Barros, Freud e Lacan". O autor, inspirado pelo texto freudiano "Escritores criativos e devaneios" e pelo conceito lacaniano de objeto $a$, lança um olhar sob a singularidade na poesia de Manoel de Barros, mostrando que seus poemas retratam o sujeito em sua simplicidade, incompletude, ao mesmo tempo que propõe o homem como funcional, mesmo quando ele perde seu lugar idealizado. Tiago também mostra que qualquer "conduta que idealize o homem, a vida e principalmente a felicidade", encontra-se na contramão tanto da poesia manoelesca quanto da psicanálise.

Em "Quando eu perdi você, ganhei a aposta: amor e desejo na novela $\mathbf{A}$ Dócil de Dostoievski", as autoras Caciana Linhares Pereira, Camila de Souza Ricarti e Roseane Torres de Madeiro mostram como uma obra literária pode retratar o modo de operar do psiquismo humano, antecipando descobertas feitas por Freud a partir da clínica. As autoras destacam como, na novela, a intricada relação entre o desejo e o amor evidenciam detalhes relacionados à dinâmica da neurose obsessiva, indicando a presença de um impossível na experiência amorosa.

A literatura também serviu de balizamento para Camila de Freitas Moraes e Roseane Torres de Madeiro, na construção do artigo "Violência conjugal e ciúme numa perspectiva psicanalítica a partir de Otelo - 0 mouro de Veneza". A obra shakespeariana que aborda o tema dos ciúmes a partir da história de Otelo e Desdemona foi retomada pelas autoras para pensar o problema da violência conjugal 
pela perspectiva da psicanálise. Elas investigam como a subjetividade de cada sujeito se apresenta na relação amorosa, quando ocorre um ato de violência contra a mulher em decorrência do ciúme. A partir de um percurso em Freud, destacam como o ciúme se apresenta como um afeto intimamente vinculado à noção de desamparo primordial, um fato que é inerente à condição humana.

$\mathrm{Na}$ seção de artigos livres, destacamos o artigo "Corpos que caem: adolescência, prisão e psicanálise", de autoria de Adriele Cardoso Sussuarana, Alba Caroline Tavares dos Santos e Aleson Hernan Morais dos Santos. Os autores retratam sua experiência com adolescentes cumpridores de medidas sócio-educativas que se encontram em situação de privação de liberdade na cidade de Macapá-AP. O relato destaca como um trabalho em que a intervenção com exercícios corporais, abriu caminhos para a instalação de um dispositivo clínico de escuta desses adolescentes. A ênfase do texto recai para a afirmação de que a psicanálise não pode ser reduzida ao espaço clínico do consultório, podendo balizar com seu referencial teórico praticas que evidenciam sua eficácia, sobretudo no campo social.

Bruno Wagner D'Almeida de Sousa Santana defende em seu texto "Totem e Tabu: vida cotidiana", a ideia de Freud não se alia a uma gama de pensadores que defendem progresso da razão, da civilização e da humanidade, como afirma. Ao contrário, para o autor, Freud na verdade teve como foco um olhar sobre o mal-estar que surge como um preço a ser pago pelo homem pelo surgimento da civilização. Bruno Wagner ressalta que essa perspectiva resulta do fato de Freud ter vivido no período em que deflagraram as duas grandes guerras mundiais que assolaram a humanidade, colocando em xeque toda racionalidade humana, ao mesmo tempo que evidenciaram a linha tênue que separa a civilização da barbárie.

Ainda nessa edição, destacamos o texto "Um estudo sobre a melancolia: breve percurso da psiquiatria à psicanálise freudiana" de autoria de Gladson Henrique Silva, onde encontramos um breve histórico a respeito de como a melancolia era pensada pela psiquiatria, até o momento do surgimento da psicanálise quando uma nova maneira de enxergar essa patologia foi introduzida por Freud. O autor ressalta o percurso de teorização freudiana, quando inicialmente Freud pensava a melancolia como um quadro que compunha as neuroses narcísicas, para tempos depois, situá-la no contexto das psicoses.

Em "A metapsicologia do recalque", Carlos Eduardo Rodrigues, Cassiano Carlos Antônio de Oliveira, Daniela Paula do Couto, Elizabeth Fátima Teodoro, Felipe 
Alcides Gonçalves Ribeiro, Geane Moares Coelho, Mardem Leandro Silva e Roberto Lopes Mendonça, participantes de um grupo de pesquisa que investiga os conceitos fundamentais da psicanálise, retomam com rigor a temática do recalque, evidenciando sua importância para a regulação da pulsão e sua função na estruturação do psiquismo humano.

A seguir, Barbara Sinibaldi, Gabriel Pavani Brandino e Thassia Souza Emidio apresentam uma interessante exposição a respeito da temática do feminino em "A psicanálise de Freud e a psicanálise de hoje: as vicissitudes do feminino na era dos extremos". O trabalho trás reflexões a respeito do que mudou na atualidade, em relaçao ao que foi formulado por Freud, na visão dos psicanalistas, acerca da abordagem do feminino, e da própria concepção de mulher. O objetivo dos autores é evidenciar como em cada época a realidade social interfere na construção de um saber sobre o feminino, muitas vezes relacionado de forma equivocada, a questão do gênero. Por fim, Joyce Bacelar Oliveira retoma o conceito psicanalítico de transferência em "The nuances of demand in the analytic discourse: a lacanian perspective", para pensar a questão da entrada em análise a partir do momento em que o sujeito formula uma demanda de análise. A autora, a partir do ensino de Lacan, destaca alguns aspectos relevantes do manejo da demanda pelo analista na condução do tratamento.

Fechamos a edição com uma interessante resenha escrita por Bruno Albuquerque, do livro "Experiência Mística e psicanálise" de autoria de Ricardo Araújo, publicado pela editora Loyola em 2015. Bruno percorre a obra apontando como a consistência teórica do autor surpreende o leitor à medida em que distingue de forma particularmente clara o campo da mística do campo da psicose.

Uma excelente leitura!

() 2018 Psicanálise \& Barroco em revista

http://www.seer.unirio.br/index.php/psicanalise-barroco/index

revista@psicanaliseebarroco.pro.br

Programa de Pós-Graduação em Memória Social — UNIRIO

Memória, Subjetividade e Criação

www.memoriasocial.pro.br/proposta-area.php

10 Psicanálise \& Barroco em revista | v.16, n. 01 | julho de 2018 